\title{
THE FOREIGN DIRECT INVESTMENTS EFFECTS ANALYSIS IN ROMANIAN BANKING SYSTEM
}

\author{
STANESCU, M[aria] C[ristina]; NEDELESCU, D[umitru] M[ihai] \& PREDA, O[ana]
}

\begin{abstract}
Foreign direct investments (FDI) represent a dynamic element of the global economy and one of the major financing sources of the emerging markets. Being a stimulant for the host-country economy, besides the capital raise effect through the cash-flow, the foreign investments bring new technologies, reorganization of some activities and increases of the labor yield and the production efficiency. Foreign investments, especially the direct one, beside the exports represent the main way of economic development. This study tried to identify the opportunities and risks of the FDI on the Romanian banking system.

Keywords: direct investments, banking system, economic strategies, credit risk, global crisis
\end{abstract}

\section{INTRODUCTION}

The tough international context represents a challenge to the financial stability in Romania. The global economy can be touched by a decrease of development, especially in the case of developed economies. Besides, the shifting through contagion of the negative effects caused by the debt crisis of some states in EU and USA as well as the vulnerability maintenance in some of European banking systems can cause some repercussions on the economic development in Romania, on the banking system capacity to access founds and the quality of the assets. [5]

We have chosen this subject because we believe that the FDI have a major influence on the banking systems in general but especially on the Romanian banking system and also on the cutting down of the implied risks. Romania currently ranks tenth position in the EU, foreign direct investment from other member states, of 8.1 billion, and ranks 14th in the EU, as foreign direct investment received from outside the EU, 0.8 billion. Considering Romania a possible location for their business development, foreign investors look closely advantages of our country for the attracting FDI, these advantages are of several types, namely:

Market advantage and geographical location:

- one of the largest markets in Central and Eastern Europe with over 19 million inhabitants;

- gate access to EU market;

- located at the crossroads of the European Union (EU), the Balkans and the Commonwealth of Independent States (CIS), Romania is crossed by three important Pan-European corridors: Corridor 4 which connects the west to Eastern Europe, Corridor 9 which connects the northern and southern, Corridor 7 continent, which facilitates navigation within Europe.

Benefits payable resources:
- highly qualified workforce at competitive prices;

- rich natural resources, including surface and underground waters, fertile agricultural land, oil and natural gas;

- significant tourism potential.

The benefits of international relations:

- bilateral agreements concluded by Romania with other states on the promotion and reciprocal protection of investments;

- bilateral diplomatic relations with 177 countries of the 191 UN member states;

- free trade treaties with the EU, Central European Free Trade Agreement (CEFTA);

- member of the World Trade Organization (WTO) in January 1995.

Economic benefits:

- $\quad$ sustained economic growth;

- downward trend of inflation;

- increased interest from foreign investors as the main destination of FDI inflows in the region;

- sound fiscal policies.

Major weaknesses of the Romanian economy are following this period of global crisis:

- exacerbation consumption and consumption especially on debt (very risky in terms of international financial turmoil);

- lack of stimulating domestic savings, its rate to GDP reaching $13 \%$, the lowest level among the member states;

- the betting on attracting foreign savings, by way of loans, which have come to cover more than half of the current account deficit;

- belief that FDI, regardless of their structure will generate the necessary resources for several years the current account balance, but in practice it appears that most FDI has been directed over the past three to four years, to trade, transactions real estate, banking and insurance, i.e. excellence areas will not ever generate export surpluses, on the contrary, will always require increasing imports;

- lack of attention to FDI in exactly those services that could generate surpluses for export, tourism and transport respectively.

Among the solutions to counter vulnerabilities we can include: 
- greater attention to commercial banks to stimulate domestic savings, while reducing lending attracted from outside;

- drastically limiting consumption through a conservative mix of monetary, fiscal and wage;

- a policy of encouraging differentiated by authorities FDI in sectors with export potential (manufacturing, tourism, transport) than areas without such potential (trade, real estate, banking and insurance).

\section{Direct effects of global crisis felt in Romania are:}

- decrease in industrial production: dependence on international demand. Industry is part of the international production chain. (70\% of Romanian exports is in the Euro area);

- reducing exports and imports;

- reducing the flow of foreign capital;

- RON depreciation and high volatility;

- risk premium and the cost of financing.

The indirect effects of global crisis felt in Romania are:

- stopping strongly affected by cost loan funding and increasing uncertainty;

- increased unemployment, reduced wealth led to population decline in consumption;

- reducing internal and external demand and increased financing costs reposition investment plans or delay resulting decrease investment in the economy;

- risks to financial stability, such as increasing nonperforming loans, reducing profits and lack of financing companies;

- decrease in budget revenues that result as the first high budget deficit.

Romania's stabilizing factor in the global crisis.

Romania has received a loan of 20 billion EUR, consisting of 12.9 billion EUR from the IMF, 5 billion EUR from the European Union, 2 billion EUR from the European Bank for Reconstruction and Development (EBRD) and the World Bank (WB). Reimbursement of financial support will be made by 2015 .

New international banks operating in Romania and are committed to maintain credit lines to continue operations in Romania and to provide additional funding if it proves necessary. The European Investment Bank (EIB) will support the Romanian economy by 1 billion annually for investment projects. This year, Ford and Renault could attract more than 600 million, loans guaranteed by the Romanian state. The European Bank for Reconstruction and Development (EBRD) intends to increase to 500 million EUR annual volume of financing granted in Romania and even exceed this level, half of the amount will be directed in the financial sector. We consider that Romania will remain an attractive destination for FDI and profitable decision being influenced by foreign partner's macroeconomic developments in the real economy and economic efficiency calculations. The deployment of the financing agreement with EU and International Monetary Fund (IMF) sustained the application of the cautious macro policies.

The European initiative for banking coordination was good for the financial stability, the nine attendees fulfilling together the commitment of individual capitalization of the Romanian financial institutions over $10 \%$.

The new stand-by agreement signed with EU, IMF and World Bank (WB), as well as other arrangements taken in the national programmers are lifelines for financial stability maintenance and for the ongoing structural reforms in order to stimulate the economic development. [4]

\section{MAJOR RISKS OF THE ROMANIAN BANKING SYSTEM ACTIVITY}

In order to lessen as much as possible the possible negative effects generated by contagion, the National Bank of Romania is permanently watching carefully the prudential status of the banks. [5] Currently the main risks facing the Romanian banking system are:

Market risk is the risk of incurring losses or failure estimated profits arising from fluctuations in market prices, rates interest and exchange rate, market risk arising from customer-related activities and taking positions in financial instruments. The small size of their own trading activities and trading book character (which mainly includes currency positions), and also open foreign exchange position limit risk profile indicates a low rate. however, cross selling techniques of treasury products reflects a conservative approach to market risk, because banks generally do not act on their own and only as a broker for clients Romanian banking system.

Currency risk is an element of market risk arising from exchange rate fluctuations.

Open foreign exchange positions are a source of risk, major currencies held as EUR and USD. to avoid losses that may arise from adverse movements in exchange rates, banking institutions monitor assets and liabilities by currency in order to obtain a balanced distribution currencies, maintaining a margin FOREX position $( \pm$ $10 \%$ ) of its own funds for every device and $20 \%$ overall foreign exchange position limits laid down by the Romanian National Bank (RNB). [2] [3]

Operational risk is the risk of loss or failure to record the estimated profits that are caused by internal factors (inadequate domestic activities, inadequate systems or personal) or external factors (economic environment, changes in banking, technology developments).

The overall objective of the bank is to manage operational risks in correspondence with the best practices in the banking industry. It manages operational risk by identifying, assessing, monitoring, mitigation and control of such risks. Operational risks occurring processes, activities and products are identified and measured by qualitative evaluation methods.

Business continuity plan includes all measures and procedures for continuing the work considered critical if neefavorabile circumstances, such as lack of personnel or system malfunction. Continuity plan priority is to protect the bank against significant losses that can threaten the very existence of the Romanian banking system.

Risk from outsourcing - outsourcing of activities by the bank is using a third party in order to carry out 
permanent, normally should be carried out by the bank. Outsourcing may be the initial transfer of assets to a third party or subsequent transfer of an activity by a third party to another (subcontracting).

Outsourcing of an activity will only bank under contracts with companies and related ancillary services in writing; clearly stating all material respects the outsourcing plan including rights, responsibilities and expectations of all parties.

Reputational risk is the risk of loss or failure to record the estimated profits due to lack of customer confidence in the integrity Romanian banking system. New banking products are created making allowance for ethical reasons which belongs to business strategy. These attend to the increase of business opportunity, but also to the decrease of the credit risk and the image risk.

The new mission of the Romanian banking system is to develop a long-term stable and profitable system which should emphasize in the future on some markets and middle-class individuals, based on high technology platform. For this the system suggests mainly the following:

- a development of the banking network;

- redefining products portfolio by identifying retail and corporate areas not yet addressed;

- continue to implement projects about standardized approach for credit risk, the introduction of internal rating system at every bank.

Interest rate risk is a component of market risk arising from the fluctuations of the interest rates on the market.

Current and planned activities provide information on the risk appetite of the Romanian banking system and interest rate risk materializing. As a result of using products with variable interest rate, the interest rate risk profile is low.

Banks' exposures to interest rate risk include only structural exposures. The main type of interest rate risk to structural positions is the interest rate risk reproach: mismatches between maturities and reproach times of the interest rate of the assets and liabilities. Changing the interest rate on the market affects directly the revenues and expenses related to assets and liabilities bearing variable interest rates and the real value of fixed interest bearing. For financial assets and liabilities in RON, the banks carry on to match the current market interest and to obtain a positive margin interest. For financial assets and liabilities in foreign currency, the banks are trying to maintain a balanced net position regarding the limits set by the central bank (RNB). To this effect most of the assets and liabilities in foreign currency interest-bearing have variable interest rate which is related to the changes of the market interest rates.

Credit risk. The banks are exposed to credit risk, or non-recovery risk claims on debtors as a result of lending short, medium and long term credits to the customers. Also, credit risk manifests due to investments in other local and foreign credit institutions. Banks minimizes this risk by carefully evaluating loan applicants and by monitoring these during the credit and by setting exposure limits. Banking institutions also monitors the selection of correspondent banks with ratings that should express the lowest risk. To this end these set limits for transactions with other banks on deposits and foreign exchange. Credit risk is the risk of incurring losses or failure of expected profits as a result of not honoring by the counterparty the contractual obligations.

The main objective regarding the credit risk management is to maximize the risk/profit rapport, while maintaining credit risk exposure within acceptable parameters. Banks have developed and implemented comprehensive policies and procedures to identify, estimate, monitor and control credit risk, these using different approval procedures for loans with high risk and low risk.

Low risk credit transactions are those transactions which consist in providing to the customers standardized products. All customers requiring standardized products of the Romanian banking system must be analyzed by using a scoring tool. Customized products furnished to customers are included in high-risk transactions class and should be granted based on a rating system.

It will be implemented an early warning system of potential customers with problems in order to detect early signs of defacement in the reimbursement debtors' capacity and to trigger closer monitoring process to prevent further damage.

Liquidity risk. Banking institutions aim to maintain a balance between investments maturity and attracted sources according with norms issued by the Romanian National Bank (RNB) [4]. Liquidity risk is the risk of incurring losses or failure of the estimated profits resulting from credit institutions unable to honor payment obligations at any time the short term obligations without incurring costs or losses that may not be supported by credit institutions.

All business units of the financial institution have a shared resource - liquidity - and therefore, banks situate the liquidity risk within the category of material risks.

Liquidity risk includes the risk of recording an unexpected growth of the financing price (for refinancing portfolio assets at appropriate maturities) and the risk of inability to liquidate a position at an appropriate time and/or at a reasonable price. Banks have a degree of flexibility in the achievement of financing requirements by maintaining multiple sources of liquidity.

These are financing their operations mainly by attracting deposits from the retail and corporate depositors. In addition, these can use various maturities of the credit lines to ensure a long-term financing source or they can raise funds by selling held investments.

\section{THE FOREIGN DIRECT INVESTMENTS EFFECTS ON THE ROMANIAN BANKING SYSTEM}

It can be seen increased competition, especially for grabbing market "retail banking" (for individuals available to banks cheap funding) that will facilitate the development of new banking products and services for this segment, including complete financial services package.

Short-term strengths of the Romanian banking system: 
- banking system plays an active role in selecting companies that will receive credit performance, which leads to a more efficient lending process;

- vigilant monitoring and prudential measures;

- improvement of loan / deposit ratio;

- use of guarantee schemes and incentives to attract funds from international institutions;

- rapid adaptation to the changed conditions of the banking system by: demotivation stimulate saving and consumption by attracting deposits with attractive interest rates and tighter credit conditions and liquidity by attracting the public to support the financing needs of companies.

Long-term strengths of the Romanian banking system:

- better integration of capital raised;

- bank management commitment to develop longterm strategies;

- access to international markets through the parent banks;

- financial intermediation process will continue to converge towards the Western Europe.

Romanian National Bank (RNB) decide not only on the free entry of foreign banks but often and how their input on the basis of their evaluation input on how governments provide facilities that can encourage foreign banks to be present respective markets following a greenfield investments or acquisitions. [1]

\begin{tabular}{|c|l|}
\hline \multicolumn{2}{|c|}{ Strengths } \\
\hline $\mathbf{1}$ & $\begin{array}{l}\text { Strong parent banks, which add value to the franchise, while the } \\
\text { bank continues to strengthen the group. }\end{array}$ \\
\hline $\mathbf{2}$ & Coverage of the banking network. \\
\hline $\mathbf{3}$ & Recognized expert on internet / mobile banking. \\
\hline $\mathbf{4}$ & Integrated IT system. \\
\hline $\mathbf{5}$ & Quick response to customer. \\
\hline $\mathbf{6}$ & Competitive retail products. \\
\hline $\mathbf{7}$ & Flexibility to changes. \\
\hline \multicolumn{2}{|c|}{ Weaknesses } \\
\hline $\mathbf{1}$ & $\begin{array}{l}\text { Poorly trained staff / high turnover of staff / poor English } \\
\text { knowledge }\end{array}$ \\
\hline $\mathbf{2}$ & Poorly defined organizational structure. \\
\hline $\mathbf{3}$ & In-house IT solutions. \\
\hline $\mathbf{4}$ & Poor communication and poor teamwork culture. \\
\hline $\mathbf{5}$ & High concentration of deposits from business customers. \\
\hline $\mathbf{6}$ & Strategic partnerships and limited alternative channels. \\
\hline \multicolumn{2}{|c|}{ Opportunities } \\
\hline $\mathbf{1}$ & $\begin{array}{l}\text { Strong niche player in financial markets based on existing target } \\
\text { groups and cross-selling opportunities. }\end{array}$ \\
\hline $\mathbf{2}$ & $\begin{array}{l}\text { Recognized expertise on internet / mobile banking platform with } \\
\text { the ability to pass internet. }\end{array}$ \\
\hline $\mathbf{3}$ & $\begin{array}{l}\text { Strong parent banks add value to the franchise with a focus on } \\
\text { funding projects and product development. }\end{array}$ \\
\hline $\mathbf{4}$ & Department sustainable and stable economic development. \\
\hline $\mathbf{5}$ & Access to European funds. \\
\hline $\mathbf{6}$ & Financial sector under-banked. \\
\hline \multicolumn{2}{|c|}{ Threats } \\
\hline $\mathbf{1}$ & $\begin{array}{l}\text { EU accession will increase competition due to the possibility of } \\
\text { access to non-resident banks. }\end{array}$ \\
\hline $\mathbf{2}$ & $\begin{array}{l}\text { Strong competition in the local market with strong players - } \\
\text { foreign banks. }\end{array}$ \\
\hline $\mathbf{3}$ & Decreasing margins while operating expenses will increase. \\
\hline $\mathbf{4}$ & Solutions developed in-house staff with default risk. \\
Tab. 1 SWOT analysis \\
\hline
\end{tabular}

Economic strategy is, by definition, an approach for a long time and it does not change depending on the appearance or disappearance of the international financial crisis. Equally true is that certain strategies are less vulnerable than others to the changes in the international context, and Romania has such a weak strategy.
In essence, it is about forcing growth (to reduce the gap with the Central European countries in a short time), even at the cost of generating macroeconomic imbalances such as increased external deficit or inflation.

\section{CONCLUSION}

The global economic and financial situation has influenced in a negative way the Romanian economy. These negative effects such as deterioration of credit quality, increased inflation, reduced purchasing power, increasing interbank interest rates influenced the financial results of banks. With the intention of preventing the spread of the global crisis, the authorities have imposed some measures which were reflected in the results of the Romanian banking system:

- changes of the calculation of provisions for loans in foreign currency;

- increasing the monetary policy rate;

- maintaining high rates of reserve requirements.

Increased transparency and trust in the relationship with shareholders and customers is done through publication indicatoritor banking and other bank information on the website.

Banks face many changes in the dynamic market of the Romanian banking sector, which has become more competitive; banks are increasingly using multi-channel integration routine transactions and all territorial units considering expansion and renewal programs customer loyalty. Since stable profitable growth strategy is to develop efficient and cross selling to correctly identify the most valuable customers and meet their specific needs is required:

- efficient network development banks;

- an effective development of products that can quickly meet the growing needs of clients and establish long-term customer confidence;

- strengthening risk management and skillfully treated a large number of regulatory change requiring reporting greater standardization and transparency;

- optimized both internal and external innovation following operational quality at all levels.

In conclusion, we can say that before the crisis, local banks had an excess of liquidity due to the foreign direct investments flows, but with the deepening crisis, these flows have become insufficient and in conjunction with an insufficient amount of local economies, Romanian banks have resorted more and more to lending from the central bank.

\section{REFERENCES}

[1] Uiboupin, J., (2004), Implications of foreign bank entry on Central and East European Banking Market, Kroon\&Economy no. $1 / 2004$

[2] RNB 14/2004 for the amendment and completed by Romanian National Bank no. 4/2001 on the supervision of banks' foreign exchange positions. (www.bnro.ro)

[3] Norm RBN no. 4/2001 on the supervision of banks' foreign exchange positions. (www.bnro.ro)

[4] Norm RNB no. 1/2001 completed and modified by Romanian National Bank no.7 bank liquidity. (www.bnro.ro)

[5] Financial stability report on 2012. (www.bnro.ro) 